\title{
Long-term effects of somatostatin 14 on the pituitary-ovarian axis in rats
}

\author{
Nataša M. Nestorović, Milica N. Manojlović-Stojanoski, Svetlana L. Trifunović, Nataša \\ M. Ristić, Branko R. Filipović, Branka T. Šošić-Jurjević and Verica Lj. Milošević \\ Institute for Biological Research “Siniša Stanković”, University of Belgrade, Belgrade, Serbia
}

\begin{abstract}
The long-term effects of somatostatin 14 (SST-14) on the pituitary-ovarian axis were examined. Female Wistar rats received $20 \mu \mathrm{g} / 100 \mathrm{~g}$ b.w. doses subcutaneously twice daily for 5 consecutive days in the infantile (from $11^{\text {th }}$ to $15^{\text {th }}$ day) or peripubertal (from $33^{\text {rd }}$ to $37^{\text {th }}$ day) period of life. Females treated as infants were killed in the peripubertal ( $38^{\text {th }}$ day) or adult period of life ( $80^{\text {th }}$ day), and those treated during peripuberty as adults $\left(80^{\text {th }}\right.$ day). Pituitary follicle-stimulating (FSH), luteinizing ( $\mathrm{LH})$ and somatotropic $(\mathrm{GH})$ cells, and ovaries were analyzed by stereology and morphometry. Serum FSH and LH concentrations were determined by RIA. FSH and LH cell volumes were significantly decreased in pituitaries of peripubertal females treated with SST-14 as infants, and in adult females treated during peripuberty. GH cell volume was decreased in all treated rats. In the ovaries, enlargement of the non-growing pool of follicles was detected in adult females treated during peripuberty. SST-14 applied to infant rats did not lead to changes in initial follicular recruitment, but it disturbed follicle growth and development at later stages. It can be concluded that SST-14 exerted long-term inhibitory effects on the pituitary-ovarian axis and $\mathrm{GH}$ cells in rats.
\end{abstract}

Key words: Gonadotropic cells - Somatotropic cells - Ovary — Folliculogenesis - Stereology

Abbreviations: FSH, follicle-stimulating hormone; GH, growth hormone; $\mathrm{LH}$, luteinizing hormone; SST, somatostatin; sstr, somatostatin receptor; CL, corpus luteum.

\section{Introduction}

Functionality of the hypothalamo-pituitary growth hormone (HPGH) and hypothalamo-pituitary-gonadal (HPG) axes is closely related and age-dependant (Hull and Harvey 2001, 2002). Both axes mature at puberty, and, working in tandem, growth hormone $(\mathrm{GH})$ and gonadotropins account for the somatic and physiological changes that are collectively recognized as puberty. The involvement of GH in activation of the hypothalamo-pituitary-ovarian axis is also of great importance (Hull and Harvey 2001, 2002). In early life, i.e. the infantile period, GH pulsatility is not fully established (Gabriel et al. 1992). On the other hand, blood concentrations of follicle-stimulating hormone $(\mathrm{FSH})$ and luteinizing hormone $(\mathrm{LH})$ reach maxima

Correspondence to: Nataša M. Nestorović, Institute for Biological Research, "Siniša Stanković", University of Belgrade, 142, Despot Stefan Blvd., 11060 Belgrade, Serbia

E-mail: rnata@ibiss.bg.ac.rs around day 12 of age (Ojeda and Ramirez 1972; Dohler and Wuttke 1975; Taya and Sasamoto 1988). High concentrations of circulating gonadotropic hormones during this period are partly the result of very marked FSH and LH responsiveness to the positive influence of gonadotropin-releasing hormone (Ojeda et al. 1977; Taya and Sasamoto 1988), and low responsiveness to the negative influence of endogenous estrogen due to high levels of alpha-fetoprotein (Meijs-Roelofs and Kramer 1979). At the same time, the ovaries are under strong gonadotropic influence and almost twice as many follicles begin to move into more advanced developmental stages during the second postnatal week than at later ages (Ojeda and Urbanski 1994). Therefore, factors that lower GH secretion, such as treatment with somatostatin (SST) analogs, can affect the HPGH and HPG axes. Indeed it has been shown that SST slows down the growth and tempo of reproductive maturation in female rhesus monkeys (Wilson and Tanner 1994).

SST is widely distributed throughout the central nervous system and peripheral tissues in mammals and has 
broad, mostly inhibitory effects on endocrine and exocrine secretions, as well as anti-proliferative action (Patel 1999). SST produced in the periventricular hypothalamic nucleus is a major regulator of $\mathrm{GH}$ secretion and other pituitary hormones.

Regulation of the HPG axis by SST is still not well examined. In healthy volunteers, SST inhibited LH pulse amplitude but not frequency, without affecting FSH pulsatility (Samuels et al. 1992). It reduced the serum concentration of LH, but did not affect the release of FSH in women with polycystic ovary syndrome (Prelević et al. 1990) or in male rats (Starčević et al. 2002; Milošević et al. 2004). In adult female rats, SST-14 had an inhibitory influence on both types of gonadotropic cells (Nestorović et al. 2001, 2004a).

Earlier studies have shown the presence of endogenous SST in the ovaries of various species (Mori et al. 1984; McIntyre et al. 1992; Masini et al. 1999; Zhang et al. 2009; Gougeon et al. 2010). Moreover, expression of SST receptors (sstr) was demonstrated in human granulosa (Strauss et al. 2003; Adams et al. 2004) and granulosa lutein cells (Strauss et al. 2003), mouse granulosa cells and oocytes (Gougeon et al. 2010) and rat granulosa cells (Nakamura et al. 2013). An inhibitory effect of SST on ovarian steroidogenesis in granulosa and granulosa lutein cells has also been observed (Rajkumar et al. 1992; Andreani et al. 1995; Holst et al. 1995, 1997; Nakamura et al. 2013).

We have previously shown that SST-14 inhibits gonadotropic cells and the initial phase of folliculogenesis in the infantile (Nestorović et al. 2011) and peripubertal (Nestorović et al. 2008) periods of life. However, whether these effects are long-lasting or not is less well evaluated. Therefore, the aim of this study was to examine possible long-term effects of SST-14 applied at critical periods of life, on some morphological and functional features of pituitary gonadotropic cells, the immunohistochemical and morphometric characteristics of somatotropic cells and on ovarian follicular development in rats.

\section{Materials and Methods}

Time-mated pregnant Wistar rats were housed individually and maintained in a controlled environment ( $12 \mathrm{~h}$ light/ $12 \mathrm{~h}$ dark; $22 \pm 2^{\circ} \mathrm{C}$ ), with food (Veterinarski Zavod "Subotica", Subotica, Serbia) and water ad libitum.

Two groups of infant females were injected subcutaneously (s.c.) twice daily ( 8 a.m. and 8 p.m.) with $20 \mu \mathrm{g}$ SST-14 (S9129, Sigma, St. Louis, Mo., USA) per 100 g body weight (b.w.) for 5 consecutive days between 11 and 15 days of age. The first group was sacrificed in the peripubertal period at 38 days old, and the second in adulthood at 80 days old. A third group of female rats was treated with SST-14 in the peripubertal period between 33 and 37 days old by the same schedule and later killed at 80 days of age. Each treated group had a corresponding control group, which received the equivalent volume of saline s.c. by the same schedule. The dose regimen was based on that of Rebuffat et al. (1984) except that SST-14 was administered every $12 \mathrm{~h}$ instead of every $8 \mathrm{~h}$ (Nestorović et al. 2001). Blood was collected from individual animals and the sera were stored at $-70^{\circ} \mathrm{C}$ until $\mathrm{FSH}$ and $\mathrm{LH}$ determination. The experimental protocols were approved by the Local Animal Care Committee in conformity with the recommendations provided in the European Convention for Protection of Vertebrate Animals used for Experimental and Other Scientific Purposes (ETS no. 123. Appendix A).

After removal, the pituitaries and ovaries were weighed, fixed in Bouin's solution, dehydrated and embedded in paraffin wax. Pituitary sections $(5 \mu \mathrm{m}$ thick) were stained immunohistochemically, while serial ovary sections $(6 \mu \mathrm{m}$ thick) were stained with hematoxylin and eosin (H\&E).

\section{Pituitary}

\section{Immunohistochemistry}

Series of seven sections cut through three tissue levels (dorsal, middle and ventral portions) of the pars distalis were used for immunostaining. After rehydration, the sections were stained immunohistochemically. Gonadotropic cells were visualized using the peroxidase-antiperoxidase (PAP) method, as previously described (Nestorović et al. 2001). Anti-rat $\beta$ FSH $(1: 300 \mathrm{v} / \mathrm{v})$ or anti-rat $\beta \mathrm{LH}$ polyclonal antibodies $(1: 500 \mathrm{v} / \mathrm{v})$ (National Institute of Health, Bethesda, MD, USA) served as the primary antibodies. For detection of somatotropic cells, sections were incubated with polyclonal anti-human GH antibodies (1:300 v/v (DAKO A/S, Glostrup, Denmark)) (Nestorović et al. 2008).

\section{Stereological measurements}

Immunohistochemically stained $5 \mu \mathrm{m}$ thick sections of the pars distalis were used for morphometric examination of FSH, LH and GH cells that possessed visible nuclei. Cell volumes $(\mathrm{Vc})$ and volume densities $\left(\mathrm{V}_{\mathrm{V}}\right)$ were estimated by light microscopy at $1000 \times$ magnification using the $\mathrm{M}_{42}$ multipurpose test system (Weibel 1979). Cell volumes were expressed in $\mu \mathrm{m}^{3}$, while volume densities were given as percentages of total pituitary cells per $\mathrm{mm}^{3}$. At the same time, the number of immunoreactive cells per unit area $\left(\mathrm{mm}^{2}\right)$ in each section was analyzed.

\section{Ovary}

Every second ovarian section ( $6 \mu \mathrm{m}$ thick) was examined by light microscopy. Follicle and corpora lutea (CL) num- 
bers were determined by simple point counting. Healthy follicles were divided into two groups: small follicles measuring $<275 \mu \mathrm{m}$ in the largest cross-section (LCS) and large follicles measuring $\geq 275 \mu \mathrm{m}$ LCS. Small follicles were further divided into six classes as defined by Gaytan et al. (1998) as follows: (1) primordial follicles containing an oocyte surrounded by a layer of 3-6 flattened pre-granulosa cells; (2) primary follicles consisting of an oocyte surrounded by a layer containing one enlarged cell or a whole layer of cuboidal pre-granulosa cells; (3) multilaminar class A follicles (Ma) with 1-2 layers of granulosa cells measuring up to $75 \mu \mathrm{m}$ in diameter; (4) multilaminar class $\mathrm{B}$ follicles $(\mathrm{Mb})$ measuring from 76 to $150 \mu \mathrm{m}$; (5) multilaminar class $\mathrm{C}$ follicles (Mc) measuring from 151 to $200 \mu \mathrm{m}$; and (6) multilaminar class D follicles (Md) measuring from 201 to $274 \mu \mathrm{m}$. Large follicles were divided into five classes as previously defined by Osman (1985): class I, from 276 to $350 \mu \mathrm{m}$ in diameter; class II, from 351 to $400 \mu \mathrm{m}$; class III, from 401 to $450 \mu \mathrm{m}$; class $\mathrm{IV}$, from 451 to $575 \mu \mathrm{m}$; and class $\mathrm{V}$, more than $575 \mu \mathrm{m}$ in diameter. Follicle diameters were measured (two diameters at right angles) in the LCS containing the oocyte nucleolus. Atretic follicles exhibited alterations in the granulosa layer and/or on the oocyte. Follicles that contained pycnotic granulosa cells in abundance and/or a degenerated oocyte were classified as atretic. Oocyte degeneration was apparent from the highly irregular shape and/or the presence of a pycnotic nucleus. The number of CL at different phases of development (newly formed, mature and regressive) was determined per ovary.

\section{Determination of serum hormone concentrations}

Serum concentrations of FSH and LH were measured with commercial radioimmunoassay (RIA) kits (Amersham Biosciences UK Ltd, Little Chalfont, Buckinghamshire, UK). Intra-assay and inter-assay coefficients of variation were 4.2 and $7.9 \%$ for FSH and 6.5 and $10.9 \%$ for $\mathrm{LH}$, respectively.

\section{Statistical analysis}

All results were expressed as means for five animals per group \pm standard deviation (SD). The data were tested for normality of distribution by the Kolmogorov-Smirnov test. One-way analysis of variance followed by the Newman-Keuls test was used for comparisons of differences between the groups. A probability value of $5 \%$ or less was considered as statistically significant.

\section{Results}

\section{Body and organ weights}

SST 14 applied to infant rats did not lead to a decreased body weight in the peripubertal period. However, a small but significant reduction of this parameter was noted in adulthood. Body weight of adult females treated with SST14 during peripuberty was significantly $(17.1 \%)$ lower than that of the corresponding controls (Table 1).

Absolute pituitary and ovarian weights in peripubertal females were decreased by $40.5 \%$ and $35 \%$, respectively, after SST-14 application as infants, but no reduction was noted in adulthood. Peripubertal SST-14 treatment led to a $19.7 \%$ lower pituitary weight in adult females $(p<0.05)$, while ovarian weight was not affected, when compared to the corresponding control values.

Relative pituitary and ovarian weights were $38.5 \%$ and $30.7 \%$ lower, respectively, in peripubertal females treated with SST-14 as infants.

\section{Pituitary}

FSH (follicle-stimulating hormone) and LH (luteinizing hormone) cells in the pituitary of control peripubertal and adult females were numerous, positioned throughout the pars distalis, present in groups or occasionally alone, and often in close contact with blood capillaries. They were strongly

Table 1. Body, pituitary and ovary weights of peripubertal (C, 38d) and adult (C, 80d) control females, peripubertal (SST-14 16d, 38d) and adult females treated with SST-14 in infantile (SST-14 16d, 80d) and peripubertal (SST-14 38d, 80d) period of life

\begin{tabular}{lccccc}
\hline Group & $\begin{array}{c}\text { Body } \\
\text { weight }(\mathrm{g})\end{array}$ & $\begin{array}{c}\text { Absolute pituitary } \\
\text { weight }(\mathrm{mg})\end{array}$ & $\begin{array}{c}\text { Relative pituitary } \\
\text { weight }\end{array}$ & $\begin{array}{c}\text { Absolute ovarian } \\
\text { weight }(\mathrm{mg})\end{array}$ & $\begin{array}{c}\text { Relative ovarian } \\
\text { weight }\end{array}$ \\
\hline C, 38d & $117.44 \pm 7.71$ & $5.60 \pm 0.80$ & $4.78 \pm 0.74$ & $26.17 \pm 5.53$ & $21.99 \pm 2.74$ \\
SST-14 16d, 38d & $113.33 \pm 8.17$ & $3.33 \pm 0.82^{*}$ & $2.94 \pm 0.67^{*}$ & $17.00 \pm 2.45^{*}$ & $15.23 \pm 2.69^{*}$ \\
\hline C, 80d & $253.33 \pm 8.16^{\#}$ & $11.83 \pm 1.47^{\#}$ & $4.67 \pm 0.56$ & $38.00 \pm 1.41^{\#}$ & $16.26 \pm 0.43$ \\
SST-14 16d, 80d & $235.00 \pm 13.78^{*}$ & $11.58 \pm 1.28$ & $4.93 \pm 0.45$ & $38.08 \pm 1.28$ & $16.57 \pm 0.83$ \\
SST-14 38d, 80d & $210.00 \pm 8.94^{*}$ & $9.5 \pm 1.22^{*}$ & $4.54 \pm 0.68$ & $38.17 \pm 1.94$ & $17.07 \pm 1.06$ \\
\hline
\end{tabular}

All values are given as mean \pm SD $(n=5) .{ }^{\#} p<0.05$ adult control $v s$. peripubertal control females; ${ }^{*} p<0.05$ SST-14-treatment $v s$. corresponding control females. 


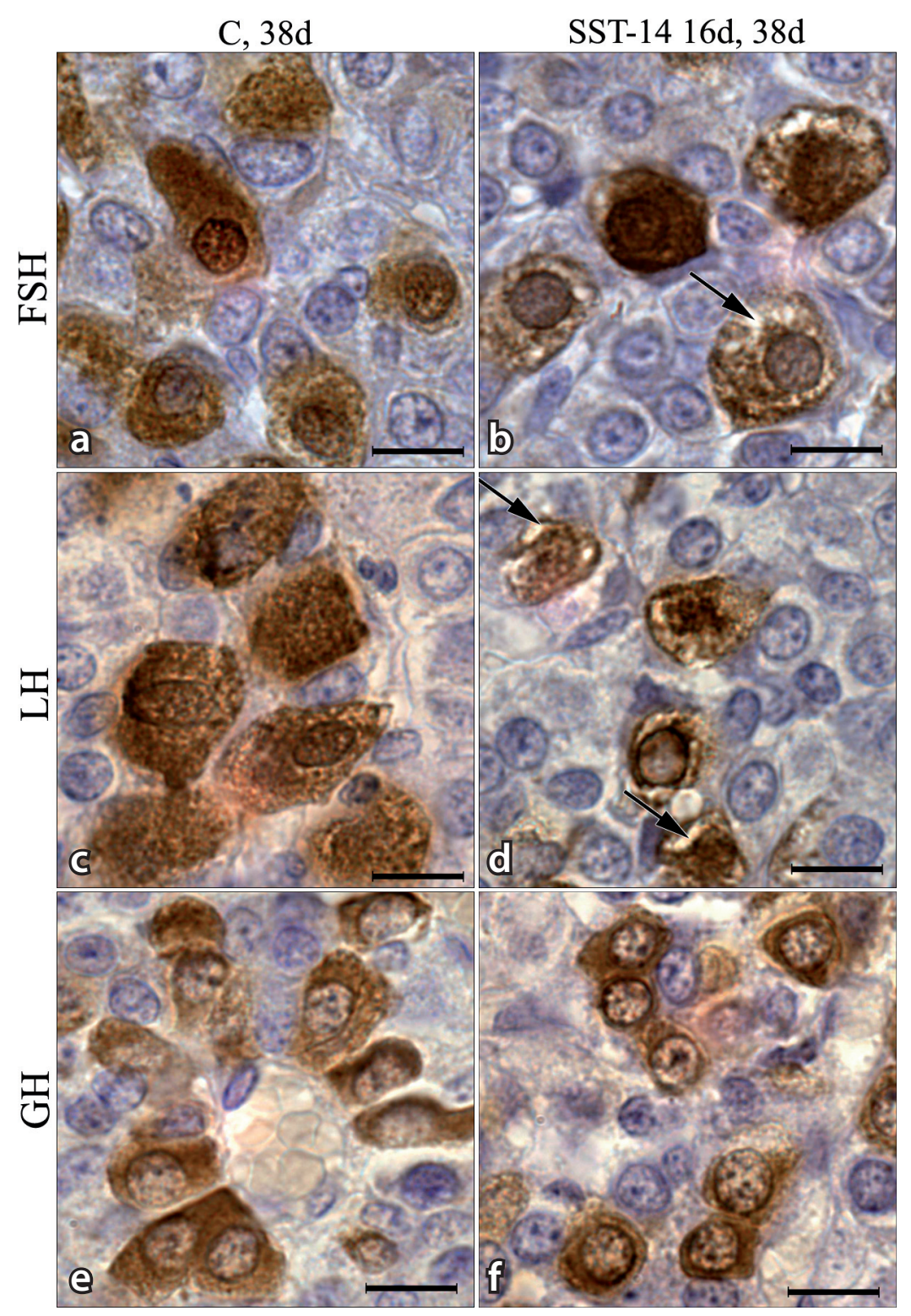

Figure 1. Representative micrographs of gonadotrops (a-d) and somatotrops (e, f) from peripubertal control (a, c, e) and peripubertal female rats treated with SST-14 as infants (b, d, f). In the pituitaries of SST-14-treated females, FSH (b) and LH (d) cells were smaller, changed in shape, with a non-uniformly stained cytoplasm (arrows). GH cells (f) were also smaller and altered in shape, bar $10 \mu \mathrm{m}$. FSH, follicle-stimulating hormone; $\mathrm{GH}$, growth hormone; $\mathrm{LH}$, luteinizing hormone.

immunohistochemically stained, large, polygonal, oval or polyhedral in shape with prominent, often eccentrically located nuclei (Figs. 1a, 1c, 2a, 2d). In the pituitaries of all treated females FSH (Figs. 1b, 2b, 2c) and LH (Figs. 1d, 2e, 2f) cells appeared smaller, when compared to the controls, with altered shapes, i.e. they were elongated and more polygonal. Their cytoplasm did not stain uniformly. Immunolabeled granules were clustered in groups and separated by unstained regions. The intensity of cytoplasmic immunostaining varied from weak to very intense (Figs. 1b, 2c).
Morphometric analysis showed that gonadotrop numbers per unit area $\left(\mathrm{mm}^{2}\right)$ were significantly decreased in the pituitaries of adult females when compared to corresponding values for peripubertal controls. This resulted in a significantly lower volume density of LH cells, while that of FSH cells was somewhat lower, but the difference was not statistically significant (Table 2).

Treatment of infant female rats with SST-14 led to decreased FSH and LH cell volume during peripuberty, by $20.9 \%$ and $23 \%$, respectively, in comparison to corre- 

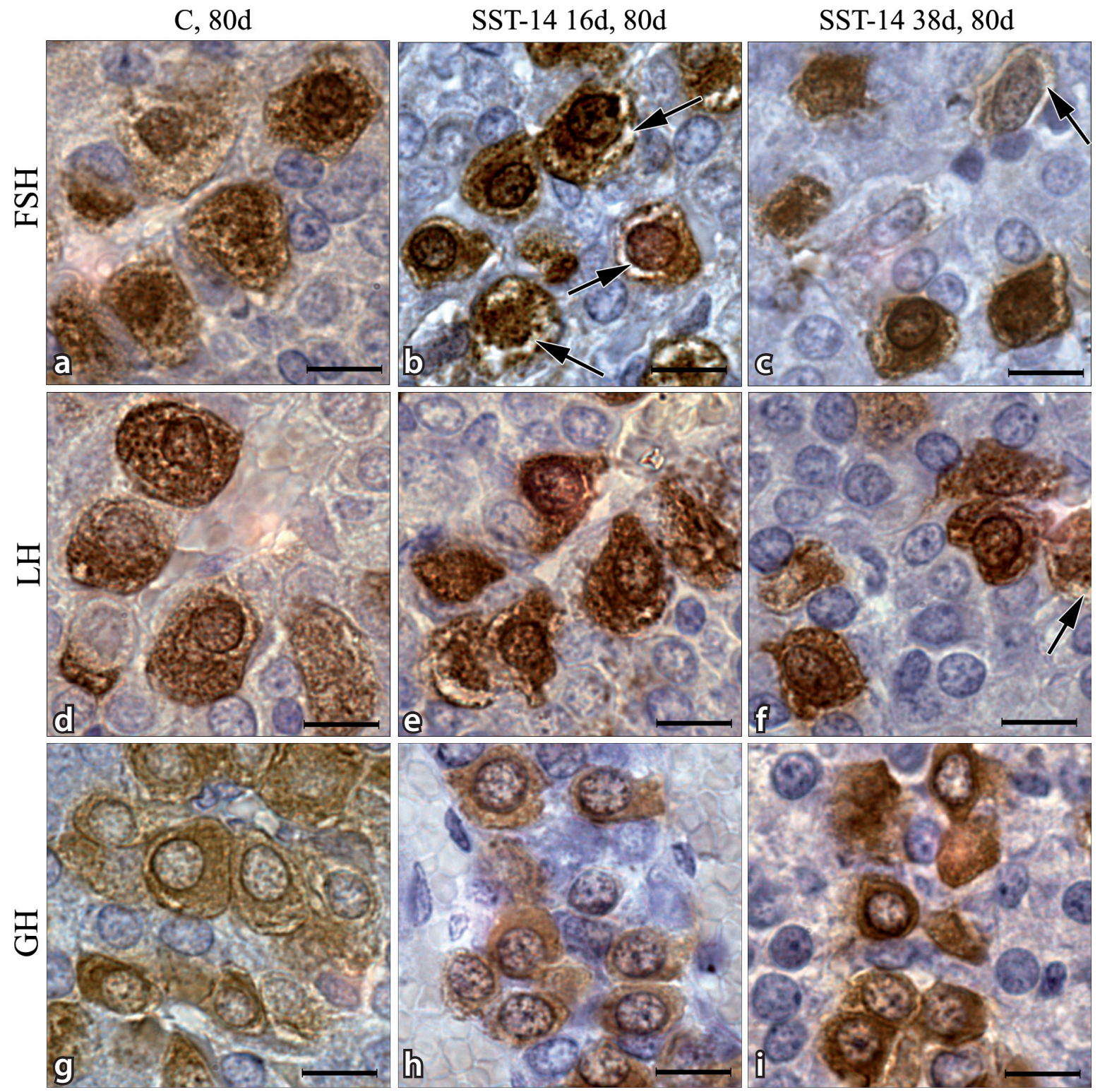

Figure 2. Representative micrographs of gonadotrops (a-f) and somatotrops (g-i) from adult control (a, d, g) and adult female rats treated with SST-14 in the infantile (b, e, h) and peripubertal periods of life (c, f, i). In the pituitaries of SST-14-treated females, FSH (b, c) and LH (e, f) cells had changed shapes, with non-uniformly stained cytoplasm (arrows). GH cells (f) were significantly smaller than in control rats, bar $10 \mu \mathrm{m}$. FSH, follicle-stimulating hormone; GH, growth hormone; LH, luteinizing hormone.

sponding controls (Table 2). When examined as adults, the volume of both types of gonadotropic cells did not differ from the values for adult control rats. The volume density of FSH and LH cells and their number per unit area did not change between the peripubertal and adult period of life (Table 2).

When applied during peripuberty, SST-14 decreased the volume and volume density of FSH cells by $21.9 \%$ and $20.8 \%$, respectively, in comparison to aged-matched adult controls (Table 2). Similarly, the volume and volume density of LH cells were $26.7 \%$ and $23.1 \%$ lower, respectively. Numbers of both types of gonadotrops per unit area were not changed by SST-14 treatment, regardless of the age when it was applied (Table 2).

GH cells were abundant in the pituitaries of control peripubertal and adult females. They were positioned throughout the pars distalis, mostly in groups in close contact with blood capillaries. Their cytoplasm was immunohistochemically stained strongly and homogenously and their shape ranged from ovoid to pyramidal (Figs. 1e, $2 \mathrm{~g}$ ). In 
A

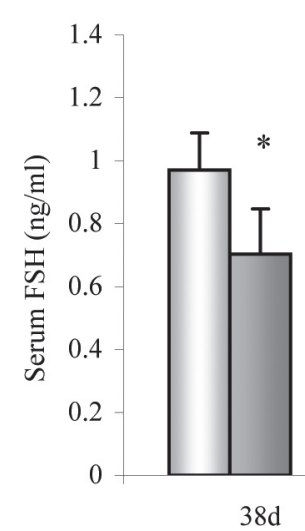

B

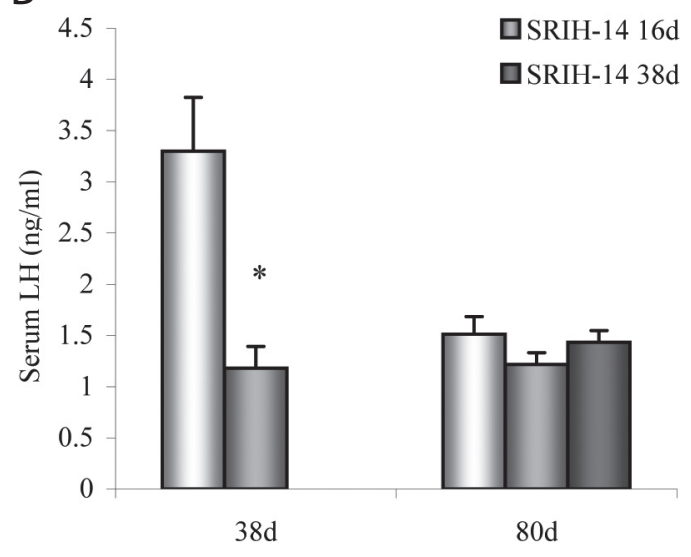

Figure 3. Serum concentrations of FSH (A) and LH (B) in peripubertal (38d) and adult (80d) control (C) females, and those treated in infantile (SST-14 16d) and peripubertal (SST-14 38d) periods of life. All values are given as means \pm SD $(n=5)$; ${ }^{*} p<0.05$ SST-14-treatment $v s$. corresponding control.

the pituitaries of all SST-14 treated females, GH cells were smaller in size than in the corresponding controls (Figs. 1f, $2 \mathrm{~h}, 2 \mathrm{i}$ ). When GH cells in the pituitaries of peripubertal and adult control rats were compared, it was evident that they were larger in adults (Figs. 1e, 2g). Namely, stereological analysis showed a significant rise of $41.6 \%$ in $\mathrm{GH}$ cell volume between peripuberty and adulthood.
Infantile SST-14 treatment diminished GH cell volume at peripuberty by $33.7 \%$ and in adulthood by $27.4 \%$, when compared to the corresponding controls. The volume density of GH cells was also lower after infantile SST-14 treatment, but the decrease (by 27.6\%) was statistically significant only when cells were examined in the adult period of life. SST-14 applied during peripuberty decreased GH cell volume and

Table 2. Cell volume $\left(\mathrm{Vc} ; \mathrm{m}^{3}\right)$, volume density $\left(\mathrm{V}_{\mathrm{V}} ; \%\right)$ and number of FSH-, LH- and GH-immunolabelled cells per unit area $\left(\mathrm{mm}^{2}\right)$ in the pituitaries of control peripubertal (C, 38d) and adult females (C, 80d) and females treated with SST-14. Pituitary cells of females treated with SST-14 in infantile period of life were analyzed in peripubertal (SST-14 16d, 38d) and adult (SST-14 16d, 80d) period of life. Pituitary cells of females treated with SST-14 in peripubertal period of life were analyzed in adulthood (SST-14 38d, 80d)

\begin{tabular}{llccc}
\hline Cells & Groups & $\mathrm{Vc}\left(\mu \mathrm{m}^{3}\right)$ & $\mathrm{V}_{\mathrm{V}}(\%)$ & $\mathrm{No} / \mathrm{mm}^{2}$ \\
\hline \multirow{4}{*}{ FSH } & C, 38d & $1305.15 \pm 120.71$ & $13.12 \pm 0.86$ & $572 \pm 46$ \\
& SST-14 16d, 38d & $1031.80 \pm 105.19^{\star}$ & $11.17 \pm 1.50$ & $602 \pm 40$ \\
\cline { 2 - 5 } & C, 80d & $1171.47 \pm 129.63$ & $10.77 \pm 0.79$ & $251 \pm 5^{\#}$ \\
& SST-14 16d, 80d & $951.46 \pm 72.46$ & $8.95 \pm 1.07$ & $266 \pm 18$ \\
& SST-14 38d, 80d & $914.62 \pm 90.69^{*}$ & $8.53 \pm 0.58^{\star}$ & $257 \pm 12$ \\
\hline \multirow{4}{*}{ LH } & C, 38d & $1319.54 \pm 67.42$ & $14.01 \pm 1.63$ & $593 \pm 23$ \\
& SST-14 16d, 38d & $1016.30 \pm 47.75^{*}$ & $11.59 \pm 0.76$ & $583 \pm 71$ \\
\hline & C, 80d & $1297.38 \pm 197.54$ & $10.12 \pm 1.58^{\#}$ & $300 \pm 10^{\#}$ \\
& SST-14 16d, 80d & $1072.28 \pm 169.06$ & $10.38 \pm 0.92$ & $283 \pm 61$ \\
& SST-14 38d, 80d & $950.61 \pm 60.23^{*}$ & $7.78 \pm 0.77^{*}$ & $301 \pm 27$ \\
\hline \multirow{2}{*}{ GH } & C, 38d & $649.43 \pm 68.03$ & $30.40 \pm 2.13$ & $2531 \pm 268$ \\
& SST-14 16d, 38d & $430.73 \pm 17.45^{\star}$ & $26.60 \pm 4.18$ & $3000 \pm 464$ \\
\cline { 2 - 5 } & C, 80d & $919.59 \pm 137.46^{\#}$ & $32.62 \pm 0.969$ & $2084 \pm 298$ \\
& SST-14 16d, 80d & $668.07 \pm 15.23^{*}$ & $23.61 \pm 0.94^{*}$ & $1925 \pm 89$ \\
\hline All & SST-14 38d, 80d & $674.84 \pm 59.68^{*}$ & $26.56 \pm 1.79^{*}$ & $2181 \pm 163$ \\
\hline
\end{tabular}

All values are given as mean $\pm \mathrm{SD}(n=5) ;{ }^{*} p<0.05$ adult control $v$ s. peripubertal control; ${ }^{\star} p<0.05 \mathrm{SST}-$ 14 -treatment $v s$. corresponding control. 
Table 3. The summarized number of healthy and atretic small growing and antral follicles and the healthy to atretic follicle number ratio, in the ovaries of control peripubertal $(\mathrm{C}, 38 \mathrm{~d})$ and adult $(\mathrm{C}, 80 \mathrm{~d})$ and SST-14 treated rats. Ovaries of females treated with SST-14 in infantile period of life were analyzed in peripubertal (SST-14 16d, 38d) and adult (SST-14 16d, 80d) period of life. Ovaries of females treated with SST-14 in peripubertal period of life were analyzed in adulthood (SST-14 38d, 80d)

\begin{tabular}{|c|c|c|c|c|c|c|}
\hline \multirow[b]{2}{*}{ Groups } & \multicolumn{2}{|c|}{ Number of follicles } & \multirow[b]{2}{*}{ Ratio } & \multicolumn{2}{|c|}{ Number of follicles } & \multirow[b]{2}{*}{ Ratio } \\
\hline & $\begin{array}{l}\text { Healthy small grow- } \\
\text { ing follicles }(\Sigma)\end{array}$ & $\begin{array}{l}\text { Atretic small follicles } \\
(\Sigma)\end{array}$ & & $\begin{array}{c}\text { Healthy antral fol- } \\
\text { licles }(\Sigma)\end{array}$ & $\begin{array}{l}\text { Atretic antral follicles } \\
(\Sigma)\end{array}$ & \\
\hline $\mathrm{C}, 38 \mathrm{~d}$ & $647 \pm 91$ & $29 \pm 3$ & $22: 1$ & $30 \pm 2$ & $65 \pm 10$ & $1: 2$ \\
\hline SST-14 16d, 38d & $350 \pm 65^{*}$ & $39 \pm 9$ & $9: 1$ & $17 \pm 5^{*}$ & $44 \pm 9$ & $1: 3$ \\
\hline $\mathrm{C}, 80 \mathrm{~d}$ & $335 \pm 53^{\#}$ & $16 \pm 5^{\#}$ & $21: 1$ & $24 \pm 4$ & $33 \pm 8^{\#}$ & $1: 1$ \\
\hline SST-14 16d, 80d & $271 \pm 30$ & $22 \pm 4$ & $12: 1$ & $16 \pm 4$ & $34 \pm 4$ & $1: 2$ \\
\hline SST-14 38d, 80d & $389 \pm 52$ & $20 \pm 4$ & $19: 1$ & $26 \pm 8$ & $38 \pm 15$ & $1: 1$ \\
\hline
\end{tabular}

All values are given as mean \pm SD $(n=5) ;{ }^{\#} p<0.05$ adult control $v s$. peripubertal control; ${ }^{*} p<0.05$ SST-14-treatment $v s$. corresponding control.

volume density, by $26.6 \%$ and $18.6 \%$, respectively, but the number of GH cells per unit area of pituitary was not changed after SST-14 treatment regardless of the time of application or analysis (Table 2).

\section{Serum FSH and LH concentrations}

Significant declines of serum FSH and LH concentrations were observed in peripubertal rats after infantile SST-14 treatment. Mean FSH concentration was 27.5\% lower and mean LH $64.2 \%$ lower than the corresponding values for control females (Fig. 3). In adult females no differences in gonadotropic hormone concentrations were observed.

\section{Ovary}

Numerous healthy follicles at all stages of folliculogenesis, as well as rare atretic follicles at different stages of degeneration, were present in the ovaries of peripubertal and adult controls (Fig. $4 \mathrm{a}, \mathrm{c}$ ). Since the peripubertal control and treated rats had not reached puberty, CL were not present in their ovaries (Fig. 4 a,b). In the ovaries of adult females, healthy newly formed and mature follicles and regressive CL were present (Fig. 4 c,d). Quantification of follicles at different stages of development showed that the number of primordial and healthy multilayered (secondary, preantral) follicles in the ovaries of control adult females was lower than in peripubertal control rats (Fig. 5a). Additionally, atretic small and antral follicle numbers were decreased by $43.4 \%$ and $48.7 \%$, respectively (Table 3 ).

The ovaries of peripubertal females treated with SST-14 as infants were well organized and follicles at all stages of development and degeneration were present. However, light microscopic examination of the ovaries revealed many fewer healthy small follicles than in controls and prevalence of atretic follicles (Fig. 4b). Indeed, the morphometric analysis showed that the number of healthy small, multilayered follicles was diminished. Significant decreases were evident in several individual classes: Ma by $48.0 \%$, Mb by $62.0 \%$, Mc by $58.9 \%$ and Md by $51.3 \%$ (Fig. 5a). The sum of healthy small follicles was $45.9 \%$ lower than for the corresponding control (Table 3). This resulted in declines within individual classes of healthy large, antral, follicles (Fig. 5b) and a significant $43.8 \%$ decrease in the sum of antral follicle numbers (Table $3)$. Fewer healthy follicles pushed the healthy to atretic follicle ratio in favor of atretic for both small and large follicles (Table 3).

Follicles and CL at all stages of development were seen in the ovaries of control adult females and those treated with SST-14 as infants (not shown). However, many fewer healthy antral follicles were observed than in control ovaries. Morphometric analysis showed fewer healthy antral follicles, but the difference was significant only for class I follicles (Fig. $5 b)$. Although the number of healthy or atretic follicles was not significantly changed, the healthy to atretic follicle ratio favored atretic for both small and large follicles (Table 3). The number of newly formed CL was similar to that for the corresponding controls, while the number of mature CL was $31.5 \%$ lower and regressive CL 52.9\% higher (Fig. 6).

Numerous follicles at different stages of development and atresia, as well as CL with slight prevalence of CL in regression were present on $\mathrm{H} \& \mathrm{E}$-stained sections of ovaries from adult females that had received SST-14 during peripuberty (Fig. 4d). Detailed histological and morphometrical analysis showed that the number of primordial i.e. non-growing, quiescent follicles, was significantly higher (by $81.0 \%$ ) when compared to the corresponding control value. Healthy or atretic small and large follicle numbers were not changed (Figs. 5a, b; Table 3). However, the numbers of young and mature CL were decreased by $50.2 \%$ and $32.2 \%$, respectively, while that of regressive CL was increased by $97.6 \%$, when compared to corresponding control values (Fig. 6). 


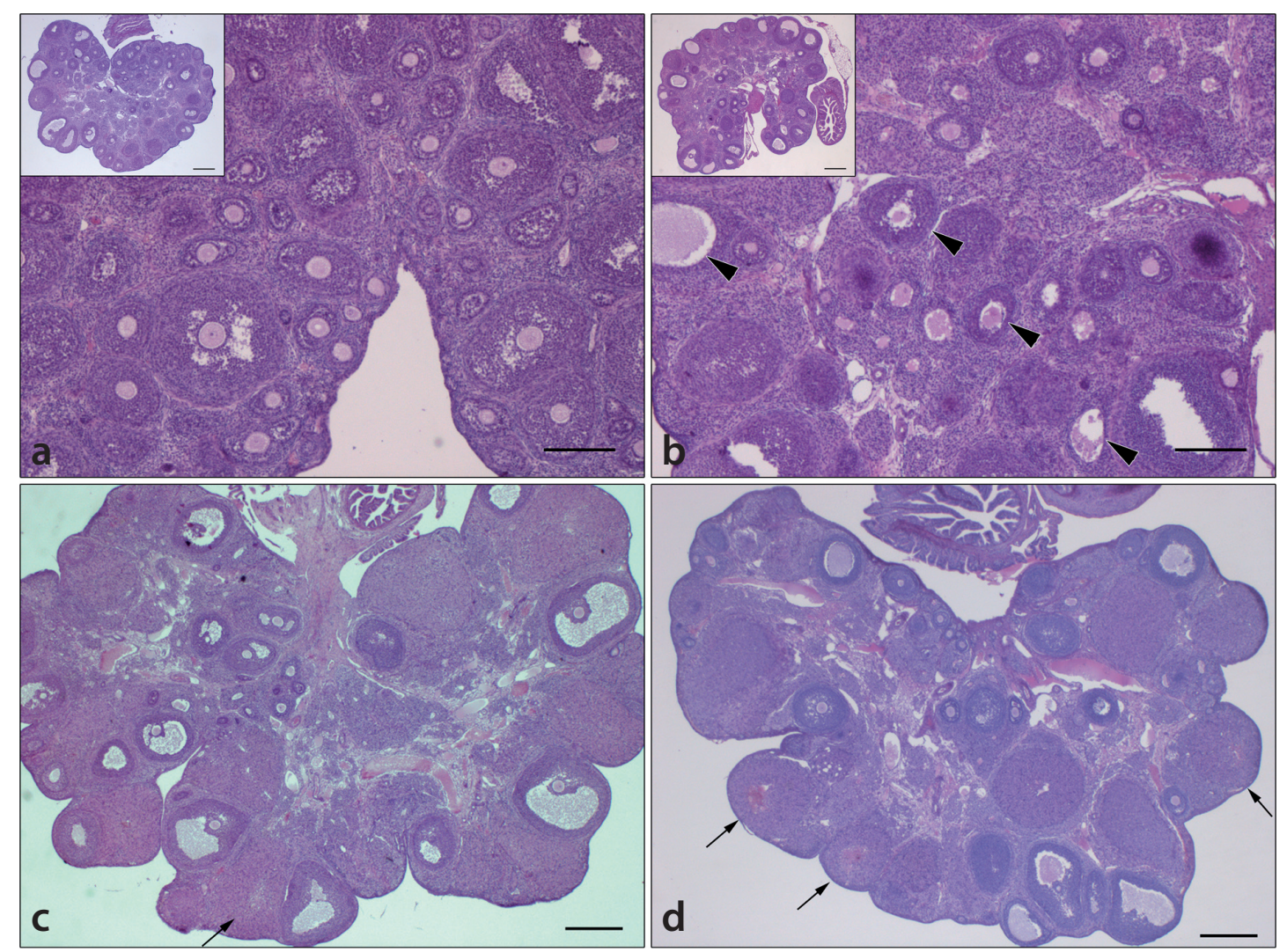

Figure 4. Representative micrographs of ovaries of a peripubertal control female (a); a peripubertal female treated with SST-14 as an infant (b); an adult control female (c) and an adult female treated with SST-14 during peripuberty (d). Ovaries of control females are characterized by the presence of numerous healthy follicles in various stages of development, while in the ovaries of SST-14 treated females numerous degenerated follicles in various stages of atresia (arrowheads) and regressive CL (arrows) are present (b, d). a, b, bar $40 \mu \mathrm{m}$; c, d, bar $400 \mu \mathrm{m}$. Respective whole-ovarian section is shown in the inset, bar $400 \mu \mathrm{m}$.

\section{Discussion}

Short-term inhibitory effects of SST-14 on rat pituitaries and ovaries in critical periods of life have been documented (Nestorović et al. 2008, 2011). To elucidate whether SST-14 has long-term inhibitory effects on the pituitary-ovarian axis and somatotropic cells, female rats were treated with SST-14 in the critical infantile or peripubertal period, and the effects were examined at later ages. Our results demonstrate that inhibition by SST-14, although less severe than immediately after application, can be detected in the pituitary and ovaries in later periods of life.

The biological effects of SST are mediated through five distinct receptor subtypes $\left(\operatorname{sstr}_{1-5}\right)$. All five receptor mRNAs are expressed in the rat pituitary. This is developmentally determined in a subtype-specific manner, with the expression of sstr $_{2}$ mRNA and protein rising from birth and reaching a maximum in the adult (Reed et al. 1999). The abundance of other sstr mRNAs does not change with age (Reed et al. 1999). Therefore, in our experimental conditions, SST-14 could directly inhibit pituitary cells, since the sstrs are expressed at the ages when SST-14 was applied, and this hormone has the same affinity for all types of sstrs (Patel 1999).

However, since SST-14 was applied systemically and not centrally, an inhibitory effect on gonadotropic and GH cells, mediated through inhibition of specific hypothalamic-releasing factors cannot be excluded. The somatostatin analog, octreotide, was shown to inhibit activation of gonadotropin-releasing hormone $(\mathrm{GnRH})$-containing cells in the hypothalamus of ovariectomized adult rats (Van Vugt et al. 2004) and expression of $\operatorname{sstr}_{2-4}$ mRNA was detected in mouse GnRH neurons (Todman et al. 2005). SST inhibits secretion of growth hormone-releasing hormone (GHRH) (Giustina and Veldhuis 1998) and expression of sstrs was demonstrated in the rat arcuate nucleus even during the neonatal period of life (Thoss et al. 1995).

The dominant effect of SST on pituitary function is inhibition of hormone secretion, mostly as a result of acute inhibition of hormone exocytosis (Ben Shlomo and Melmed, 2010). However, in our study we observed a long-term 
effect of SST-14 on gonadotropic and somatotropic cells after multiple treatments of infant and peripubertal rats. By adulthood, gonadotropic cells showed signs of recovery in terms of blood concentrations of both FSH and LH but gonadotropic cell morphology still showed signs of inhibition. Thus, morphometric parameters did not reach adult control values after peripubertal SST-14 application. Higher sensitivity of gonadotropic cells in the peripubertal period could be expected, as $\operatorname{sstr}_{2}$ expression in the pituitary rises with age (Reed et al. 1999) and the dominant types of sstrs in LH cells are $\operatorname{sstr}_{2}$ and $\operatorname{sstr}_{1}$. Low but similar amounts of all sstrs are expressed in FSH cells (O'Carrol and Krempels 1995).

SST-14 has a long-term inhibitory effect on GH cells, as judged by their morphology and morphometric parameters. Thus, GH cell volume did not recover till adulthood after SST-14 application to both infant and peripubertal rats. In the pituitaries of control animals GH cell volume rose by $41.6 \%$ between peripuberty and adulthood. This increase in cell volume was not achieved by GH cells exposed to SST-14 in the infantile period of life. These results confirm those from an earlier study where neonatally applied SST14 markedly decreased all morphometric parameters of GH cells and these changes were sustained until adulthood (Nestorović et al. 2006). Therefore, besides the inhibitory effect of SST on pituitary hormone secretion, from our results it can be concluded that SST has an antigrowth influence on gonadotropic and somatotropic cells. Ben-Shlomo and Melmed (2010) suggested that this effect is probably mediated through induction of cell apoptosis or induction of cell senescence, rather than inhibition of mitogenesis. Indeed, pycnotic gonadotropic cells were observed after acute central octreotide administration (Nestorović et al. 2004b).
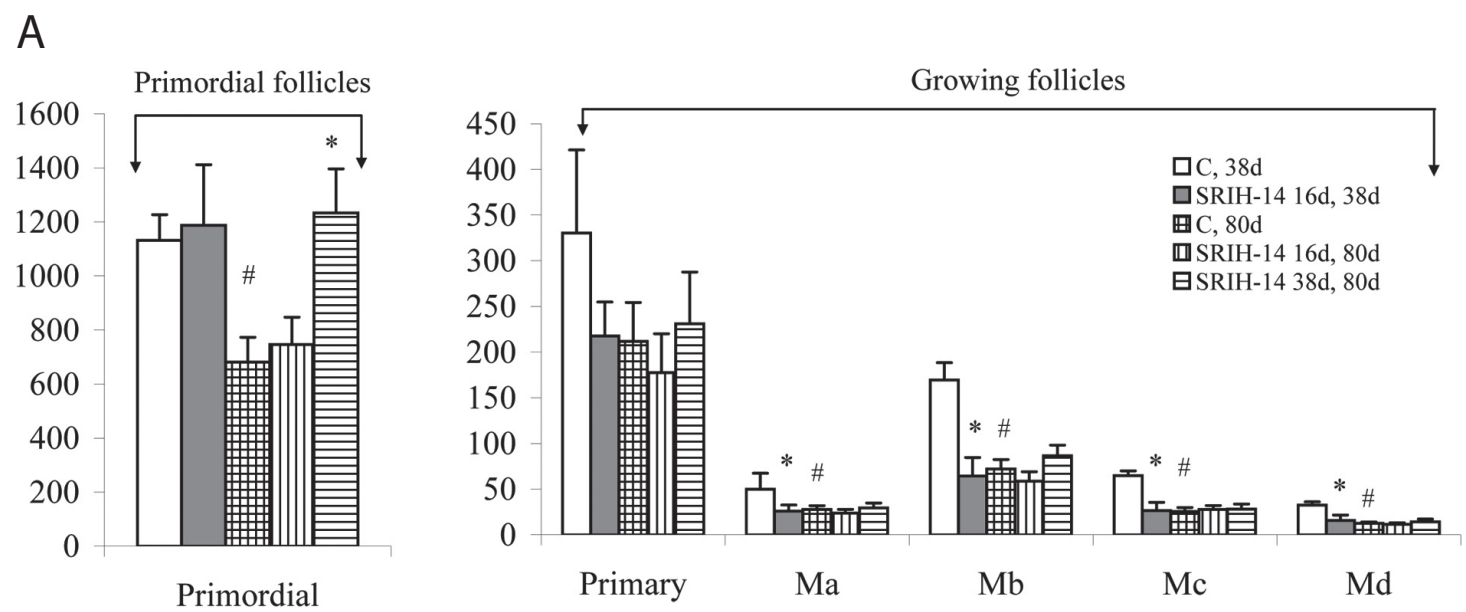

B

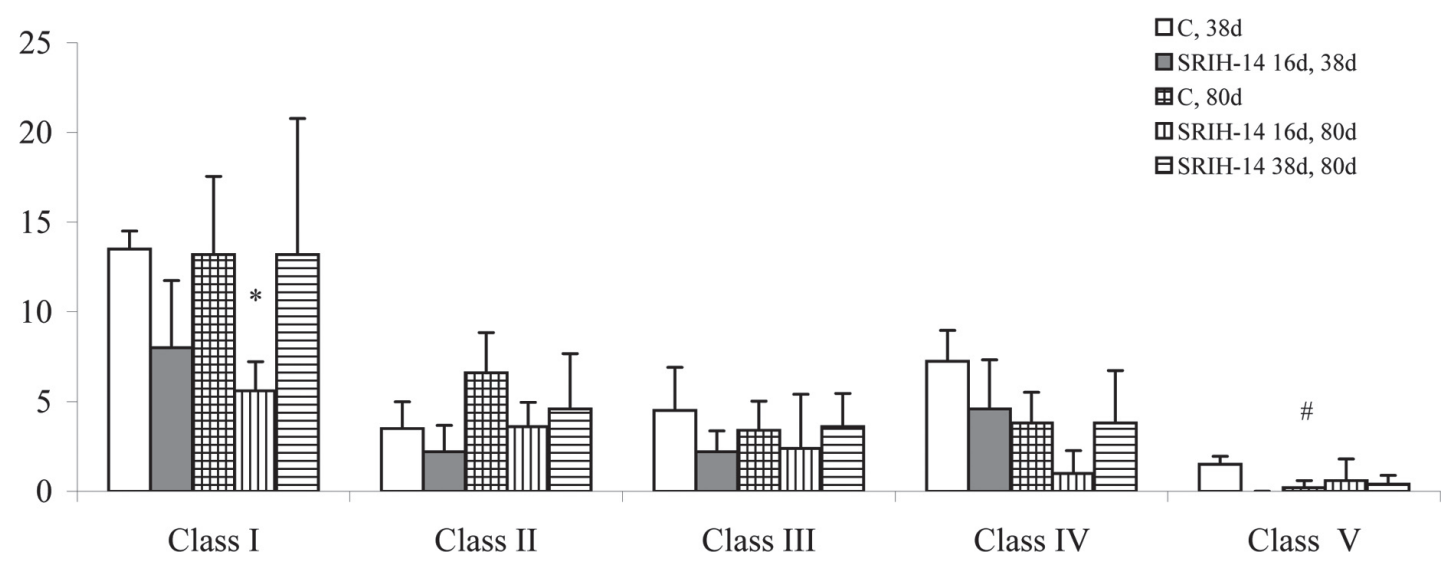

Figure 5. Average number of healthy small follicles (A) and healthy large follicles (B) per ovary of control peripubertal (C, 38d) and adult $(\mathrm{C}, 80 \mathrm{~d})$ animals, peripubertal females treated with SST-14 as infants (SST-14 16d, 38d) and adult females treated with SST-14 in the infantile (SST-14 16d, 80d) and peripubertal (SST-14 38d, 80d) periods of life. All values are given as means \pm SD $(n=5) ;{ }^{*} p<0.05$ adult control vs. peripubertal control; ${ }^{\star} p<0.05$ SST-14-treatment $v s$. corresponding control. For more details see Materials and Methods. 
The decreased absolute pituitary weight of peripubertal and adult females that had received SST-14 as infants and during peripuberty, respectively, could be the result of this antigrowth effect of SST. However, relative pituitary weight was decreased only in peripubertal females treated as infants, since SST-14 did not affect body weight. On the other hand, peripubertal application of SST-14 led to reduction of both pituitary and body weight of adult females.

In the ovary, increase of primordial follicle number was noted in adult females that had received multiple SST-14 treatment during peripuberty, while in peripubertal and adult females given SST as infants, normalization of primordial to primary follicle transition occurred. This suggests that the period of life when SST-14 is administered determines the effect of this hormone on the non-growing pool of follicles. This is in accordance with our previous findings of enlargement of the non-growing pool of follicles after application of SST-14 chronically to immature, or in multiple doses to infantile and peripubertal females (Nestorović et al. 2004a, 2008, 2011), but not if it was applied in multiple doses to adult rats (Nestorović et al. 2001).

The mechanisms that regulate the initial process of folliculogenesis still remain unclear, but it is certain that the pool of primordial follicles is under inhibitory control, since removal of ovarian tissue and its fragmentation causes the primordial follicles to move en masse towards the stage of late primary follicles (Wandji et al. 1997). Somatostatin probably enhanced the inhibitory influence on initial follicle recruitment, since in vitro treatment of mouse ovaries with an antagonist caused an opposite effect (Gougeon et al. 2010).

Although treatment with SST-14 in the infantile period of life did not have long-term consequences on primordial to primary follicle transition, an impaired process of folliculogenesis can be seen at later stages, as the numbers of preantral and small antral follicles were reduced in both peripubertal and adult periods. This resulted in a decrease of absolute and relative ovary weight in peripubertal animals. In the ovaries of peripubertal and adult females that received SST-14 as infants, the healthy to atretic follicle ratio changed in favor of atretic follicles in both the small and large follicle group. This implies that SST-14 enhanced atretic processes, which contrasts with the short-term effect of SST-14 applied in the infantile or peripubertal period of life (Nestorović et al. 2008, 2011). In adult females that received SST-14 during peripuberty, enhancement of atretic processes was not noted, which could suggest that the age when SST-14 is administered determines its effect on follicular atresia.

Disturbed folliculogenesis was also seen at the level of CL. The overall number was not significantly changed, but regressive CL had increased at the expense of healthy ones. Thus, the ratio of healthy newly formed and mature CL to regressive ones was disturbed in adult females treated with SST-14 during peripuberty in the same manner as in those treated as infants. An inhibitory effect of SST on ovarian steroidogenesis in granulosa and granulosa lutein cells has been described previously (Rajkumar et al. 1992; Andreani et al. 1995; Holst et al. 1995, 1997). Recently Nakamura et al. (2013) showed that treatment of rat granulosa cells in vitro with SST analogs at pharmacologic doses decreased FSH-induced estradiol and progesterone production with reduction of mRNA for key steroidogenic enzymes. Therefore, since survival of CL depends on progesterone (Goyeneche et al. 2003), fewer healthy CL and more CL in regression in the ovaries of SST-14 treated females could be due to decreased progesterone production.

The disturbance of ovarian folliculogenesis seen in this study could have been the consequence of a direct effect of SST on the ovary. The presence of sstrs in granulosa cells of mouse and rat ovaries has been documented (Gougeon et al. 2010; Nakamura et al. 2013). However, SST might affect ovarian folliculogenesis indirectly via pituitary gonadotropin and GH modulation, especially at later stages. Both gonadotropin hormones are

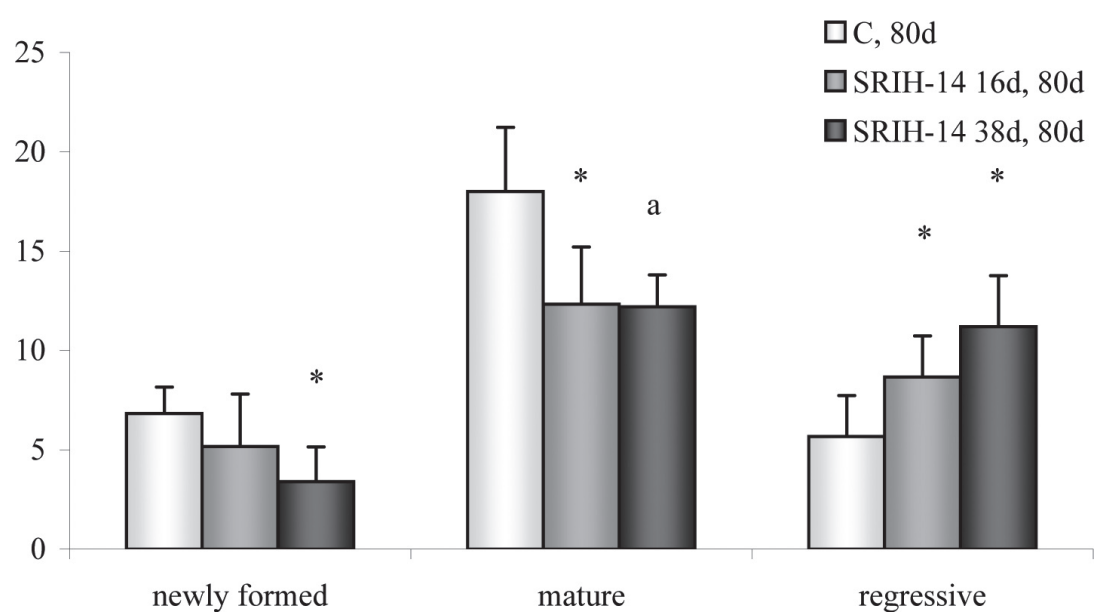

Figure 6. Average number of healthy newly formed and mature corpora lutea (CL) and regressive CL per ovary of control adult females (C, 80d), adult females treated with SST-14 as infants (SST-14 16d, 38d) and adult females treated with SST-14 during peripuberty (SST-14 16d, 80d). All values are given as means $\pm \mathrm{SD}(n=5) ;{ }^{*} p<0.05$ SST-14-treatment $v s$. control. 
necessary for maintenance and control of ovarian functions including folliculo- and steroidogenesis (Richards, 1980). Additionally, there is evidence that $\mathrm{GH}$ is also required for ovarian follicular growth (Hull and Harvey 2001, 2002; Bachelot et al. 2002). The long-lasting inhibitory effects of SST-14 on pituitary gonadotropic and GH cells shown here could negatively affect ovarian folliculogenesis. Thus, SST-14 was applied to female rats in critical periods for development and maturation of the HPG and HPGH axes. The route of SST-14 application, i.e. peripheral administration, enabled estimation of effects of SST-14 on the pituitary-ovarian axis as a whole.

To conclude, application of SST-14 to infant or peripubertal females exerted long-term inhibitory effects on pituitary gonadotropic and somatotropic cells. In the ovary SST-treatment disturbed the process of folliculogenesis creating an endocrine/paracrine environment that was less suitable for follicular growth and development.

Acknowledgements. This work was supported by the Ministry for Science of Serbia, Grant number 173009. The authors wish to express their gratitude to Dr. Anna Nikolic for language correction of the manuscript.

\section{References}

Adams I. P., Staunton B., Gilson J., Adams R. L., Robinson J., Atkin S. L. (2004): The expression of somatostatin receptors in human granulosa cells. British Endocrine Societies Joint Meeting 2004, Endocrine Abstracts 7, 185

Andreani C. L., Lazzarin N., Pierro E., Lanzone A., Mancuso S. (1995): Somatostatin action on rat ovarian steroidogenesis. Hum. Reprod. 10, 1968-1973

Bachelot A., Monget P., Imbert-Bolloré P., Coshigano K., Kopchick J. J., Kelly P. A., Binart N. (2002): Growth hormone is required for ovarian follicular growth. Endocrinology 143, 4104-4112 http://dx.doi.org/10.1210/en.2002-220087

Ben-Shlomo A., Melmed S. (2010): Pituitary somatostatin receptor signaling. Trends Endocrinol. Metab. 21, 123-133 http://dx.doi.org/10.1016/j.tem.2009.12.003

Dohler K. D., Wuttke W. (1975): Changes with age in levels of serum gonadotropins, prolactin and gonadal steroids in pre-pubertal male and female rats. Endocrinology 97, 898-907 http://dx.doi.org/10.1210/endo-97-4-898

Gabriel S. M., Roncancio J. R., Ruiz N. S. (1992): Growth hormone pulsatility and the endocrine milieu during sexual maturation in male and female rats. Neuroendocrinology 56, 619-628 http://dx.doi.org/10.1159/000126284

Gaytan F., Morales C., Bellido C., Aguilar E., Sanchez-Criado J. E. (1998): Ovarian follicle macrophages: is follicular atresia in the immature rat a macrophage-mediated event? Biol. Reprod. 58, 52-59 http://dx.doi.org/10.1095/biolreprod58.1.52

Giustina A., Veldhuis J. D. (1998): Pathophysiology of the neuroregulation of growth hormone secretion in experimental animals and the human. Endocr. Rev. 19, 717-797
Gougeon A., Delangle A., Arouche N., Stridsberg M., Gottelandm J. P., Loumaye E. (2010): Kit ligand and the somatostatin receptor antagonist, BIM-23627, stimulate in vitro resting follicle growth in the neonatal mouse ovary. Endocrinology 151, 1299-1309 http://dx.doi.org/10.1210/en.2009-0762

Goyeneche, A. A., Deis, R. P., Gibori, G., Telleria, C. M. (2003): Progesterone promotes survival of the rat corpus luteum in the absence of cognate receptor. Biol. Reprod. 68, 151-158 http://dx.doi.org/10.1095/biolreprod.102.007898

Holst N., Jacobsen M. B., Haug E., Tanbo T., Abyholm T. (1995): Somatostatin in physiological concentrations inhibits basal and enhances luteinizing hormone-stimulated progesterone release from human granulosa-luteal cells. Hum. Reprod. 10, 1363-1366 http://dx.doi.org/10.1093/HUMREP/10.6.1363

Holst N., Kierulf K. H., Seppala M., Koistinen R., Jacobsen M. B. (1997): Regulation of insulin-like growth factor-binding protein1 and progesterone secretion from human granulosa-luteal cells: effects of octreotide and insulin. Fertil. Steril. 68, 478-482 http://dx.doi.org/10.1016/S0015-0282(97)00248-3

Hull K. L., Harvey S. (2001): Growth hormone: roles in female reproduction. J. Endocrinol. 168, 1-23 http://dx.doi.org/10.1677/joe.0.1680001

Hull K. L., Harvey S. (2002): GH as a co-gonadotropin: the relevance of correlative changes in $\mathrm{GH}$ secretion and reproductive state. J. Endocrinol. 172, 1-19 http://dx.doi.org/10.1677/joe.0.1720001

Masini M. A., Sturla M., Uva B. (1999): Somatostatin in the ovary of an African lungfish (Protopterus annectens): an in situ hybridisation, immunohistochemical, and autoradiographical study. Gen. Comp. Endocrinol. 114, 287-292 http://dx.doi.org/10.1006/gcen.1999.7257

McIntyre H. D., Marechal D. J., Deby G. P., Mathieu A. G. HezeeHagelstein M. T., Franchimont P. P. (1992): Immunoreactive somatostatin in the rat ovary. Acta Endocrinol. (Copenh). 126, 553-558

Meijs-Roelofs H. M., Kramer P. (1979): Maturation of the inhibitory feedback action of oestrogen on follicle-stimulating hormone secretion in the immature female rat: a role for alpha-foetoprotein. J. Endocrinol. 81, 199-208

http://dx.doi.org/10.1677/joe.0.0810199

Milošević V., Nestorović N., Filipović B., Velkovski S., Starčević V. (2004): Centrally applied somatostatin influences morphology of pituitary FSH cells but not FSH release. Gen. Physiol. Biophys. 23, 375-380

Mori T., Saito H., Ohno Y., Irahara M., Hosoi E., Saito S. (1984) Evidence for existence of somatostatin-like immunoreactivity with molecular heterogeneity in porcine ovaries. Acta Endocrinol. (Copenh.) 106, 254-259

Nakamura E., Otsuka F., Inagaki K., Tsukamoto N., Ogura-Ochi K., Miyoshi T., Toma K., Takeda M., Makino H. (2013): Involvement of bone morphogenetic protein activity in somatostatin actions on ovarian steroidogenesis. J. Steroid. Biochem. Mol. Biol. 134, 67-74 http://dx.doi.org/10.1016/j.jsbmb.2012.10.018

Nestorović N., Lovren M., Sekulić M., Filipović B., Milošević V. (2001): Effects of multiple somatostatin treatment on rat gonadotrophic cells and ovaries. Histochem. J. 33, 695-702 http://dx.doi.org/10.1023/A:1016366704630 
Nestorović N., Lovren M., Sekulić M., Negić N., Šosić-Jurjević B., Filipović B., Milošević V. (2004a): Chronic somatostatin treatment affects pituitary gonadotrophs, ovaries and onset of puberty in rats. Life Sci. 74, 1359-1373 http://dx.doi.org/10.1016/j.lfs.2003.07.042

Nestorović N., Lovren M., Sekulić M., Negić N., Šošić-Jurjević B., Manojlović-Stojanoski M., Filipović B., Milošević V. (2004b): Effects of intracerebroventricularly administered octreotide on gonadotrophic cells in female rats. Jugoslov. Med. Biohem. 23, 149-153 http://dx.doi.org/10.2298/JMH0402149N

Nestorović N., Terzić M., Negić N., Starčević V., Milošević V. (2006): Neonataly applied SRIH-14 has immediate and prolonged inhibitory effect on pituitary GH cells. Acta Vet. 56, 457-466 http://dx.doi.org/10.2298/AVB0606457N

Nestorović N., Manojlović-Stojanoski M., Ristić N., Sekulić M., Šosić-Jurjević B., Filipović B., Milošević V. (2008): Somatostatin-14influences pituitary-ovarian axis in peripubertal rats. Histochem. Cell. Biol. 130, 699-708 http://dx.doi.org/10.1007/s00418-008-0442-7

Nestorović N., Ristić N., Manojlović-Stojanoski M., Šosić-Jurjević B., Trifunović S., Savin S., Milošević V. (2011): Somatostatin 14 affects the pituitary-ovarian axis in infant rats. Histol. Histopathol. 26, 157-166

O‘Carroll A. M., Krempels K. (1995): Wide spread distribution of somatostatin receptor messenger ribonucleic acids in rat pituitary. Endocrinology 136, 5224-5227

Ojeda S. R., Ramírez V. D. (1972): Plasma level of LH and FSH in maturing rats: response to hemigonadectomy. Endocrinology 90, 466-472 http://dx.doi.org/10.1210/endo-90-2-466

Ojeda S. R., Jameson H. E., McCann S. M. (1977): Developmental changes in pituitary responsiveness to luteinizing hormone-releasing hormone (LHRH) in the female rat: ovarian-adrenal influence during the infantile period. Endocrinology 100, 440-451 http://dx.doi.org/10.1210/endo-100-2-440

Ojeda S. R., Urbanski H. E. (1994): Puberty in the rat. In: The Physiology of Reproduction. (2nd edition, Eds. E. Knobil and J. Neill), pp 363-409, Raven Press, New York

Osman P. (1985): Rate and course of atresia during follicular development in the adult cyclic rat. J. Reprod. Fertil. 73, 261-270 http://dx.doi.org/10.1530/jrf.0.0730261

Patel Y. C. (1999): Somatostatin and its receptor family. Front. Neuroendocrinol. 20, 157-198. http://dx.doi.org/10.1006/frne.1999.0183

Prelević G. M., Wurzburger M. I., Balint-Perić L., Nešić J. S. (1990): Inhibitory effect of sandostatin on secretion of luteinising hormone and ovarian steroids in polycystic ovary syndrome. Lancet 336, 900-903 http://dx.doi.org/10.1016/0140-6736(90)92270-R

Rajkumar K., Kerr D. E., Kirkwood R. N., Laarveld B. (1992): Inhibitory action of somatostatin-14 on hormone-stimulated cyclic adenosine monophosphate induction in porcine granulosa and luteal cells. J. Endocrinol. 134, 297-306 http://dx.doi.org/10.1677/joe.0.1340297

Rebuffat P., Robba C., Mazzocchi G., Nussdorfer G. G. (1984): Inhibitory effect of somatostatin on the growth and steroidogenic capacity of rat adrenal zona glomerulosa. J. Steroid. Biochem. $21,387-390$ http://dx.doi.org/10.1016/0022-4731(84)90301-7

Reed D. K., Korytko A. I., Hipkin R. W., Wehrenberg W. B., Schonbrunn A., Cuttler L. (1999): Pituitary somatostatin receptor (sst)1-5 expression during rat development: age-dependent expression of sst2. Endocrinology 140, 4739-4744

Richards J. S. (1980): Maturation of ovarian follicles: action and interactions of pituitary and ovarian hormones on follicular cell development. Recent. Prog. Horm. Res. 32, 477-527

Samuels M. H., Henry P., Ridgway E. C. (1992): Effects of dopamine and somatostatin on pulsatile pituitary glycoprotein secretion. J. Clin. Endocrinol. Metab. 74, 217-222

Starčević V., Milošević V., Brkić B., Severs W. B. (2002): Somatostatin affects morphology and secretion of pituitary luteinizing hormone (LH) cells in male rats. Life Sci. 70, 3019-3027 http://dx.doi.org/10.1016/S0024-3205(02)01551-5

Strauss M. C., Seelig A. S., Weiss J. M., Diedrich K., Ortmenn O. (2003): Expression of somatostatin and its receptors in human ovary. Hum. Reprod. 18, 495

Taya K., Sasamoto S. (1988): Age-related changes in the secretory pattern of FSH and LH in response to LH-RH in prepubertal female rats. Endocrinol. Jpn. 35, 349-355 http://dx.doi.org/10.1507/endocrj1954.35.349

Thoss V. S., Perez J., Duc D., Hoyer D. (1995): Embryonic and postnatal mRNA distribution of five somatostatin receptor subtypes in the rat brain. Neuropharmacol. 34, 1673-1688 http://dx.doi.org/10.1016/0028-3908(95)00135-2

Todman M. G., Han S. K., Herbison A. E. (2005): Profiling neurotransmitter receptor expression in mouse gonadotropinreleasing hormone neurons using green fluorescent protein promoter transgenics and microarrays. Neuroscience 132, 703-712 http://dx.doi.org/10.1016/j.neuroscience.2005.01.035

Van Vugt H. H., Swarts H. J., Van de Heijning B. J., Van der Beek E. M. (2004): Centrally applied somatostatin inhibits the estrogeninduced luteinizing hormone surge via hypothalamic gonadotropinreleasing hormone cell activation in female rats. Biol. Reprod. 71, 813-819 http://dx.doi.org/10.1095/biolreprod.104.028936

Wandji S. A., Srsen V., Nathanielsz P. W., Eppig J. J., Fortune J. E. (1997): Initiation of growth of baboon primordial follicles in vitro. Hum. Reprod. 12, 1993-2001 http://dx.doi.org/10.1093/humrep/12.9.1993

Weibel E. R. (1979): Practical methods for biological morphometry. In: Stereological Methods. Vol. 1, pp. 1-415, Academic Press, London

Wilson M. E., Tanner J. M. (1994): Somatostatin analog treatment slows growth and the tempo of reproductive maturation in female rhesus monkeys. J. Clin. Endocrinol. Metab. 79, 495-501

Zhang L., Li W., Hong X., Lin H. (2009): Regulation of preprosomatostatin 1 (PSS1) gene expression by $17 ß$-estradiol and identification of the PSS1 promoter region in orange-spotted grouper (Epinephelus coioides). Mol. Cell. Endocrinol. 311, 87-93 http://dx.doi.org/10.1016/j.mce.2009.06.008

Received: August 21, 2013

Final version accepted: January 2, 2014 